\title{
PERTAMBAHAN BOBOT BADAN HARIAN (PBBH) PADA AYAM LAYER STARTER GROWER YANG DIBERI RESVERATROL TEPUNG BIJI ANGGUR
}

\author{
Dyanovita Al Kurnia \\ Program Studi Peternakan Fakultas Peternakan Universitas Islam Lamongan \\ Jl. Veteran No. 53 Lamongan \\ e mail : dyanovita@unisla.ac.id
}

\begin{abstract}
The purpose of this research was to examine the potention of using resveratrol of grape seed meal to increase average daily gain. The material used in this research are 60 layer poultry of 0-60 days. Resveratrol of grape seed meal devided in several level were $\mathrm{p0}=$ commercial feed withouth Resveratrol of grape seed meal, $P 1=$ commercial feed $+0.012 \%$ Resveratrol of grape seed meal, $P 2=$ commercial $+0.018 \%$ Resveratrol of grape seed meal, P3 = commercial feed $+0.024 \%$ Resveratrol of grape seed meal. Layer poultry were allotted to four level treatments randomly into P0, P1, P2, $P 3$. Three replications each. The variables observed was of increase average daily gain. Data were analyzed by using Completely Randomized Design, when there was significant effect it was followed by Duncan's Multiple Range Test. The result of this research showed that the use of resveratrol of grape seed meal doesn't differ reality $(P>0,05)$. But in the numeric showed $P 2(12.85 \pm 0.30)$ was better than all treatments $p 0(12.27 \pm 0.30)$, $P 1(12.49 \pm 0.08), p 3(12.71 \pm 0.12)$.
\end{abstract}

Key words: resveratrol, seed, grape, average, daily, gain, layer.

\section{PENDAHULUAN}

Resveratrol yang terdapat pada buah anggur dapat meningkatkan aliran darah pada otak, sehingga dapat mereduksi dan mencegah penyakit bekerja dengan menghambat senyawa benzopyrene, yaitu senyawa yang dapat menyebabkan kanker, serta menghambat pertumbuhan sel abnormal (Xia et al, 2010).

Penggunaan antibiotic growth promotore (AGP) sintetik bagi ternak umumnya digunakan untuk meningkatkan nafsu makan dan meningkatkan pertambahan bobot badan ternak dengan cepat dan efisien.

Penggunaan antibiotika pemacu pertumbuhan (AGP) sintetik untuk ternak telah dilarang diberbagai negara. Maka produk pangan yang mengandung antibiotik akan ditolak apabila masuk untuk diperdagangkan ke negara-negara lain, karena adanya persyaratan harus bebas residu antibiotik. Hal ini disebabkan: 1) kemungkinan hadirnya residu antibiotik dalam produk yang dihasilkan akan memicu timbulnya penyakit bagi konsumen dan, 2) dapat menyebabkan mikroorganisme yang ada dalam tubuh manusia maupun ternak menjadi resisten terhadap antibiotik tertentu.

Biji anggur mengandung senyawa aktif dan minyak essensial yang sangat bermanfaat bagi tubuh unggas sehingga dapat digunakan sebagai antibiotic growth promotore (AGP). Senyawa aktif dalam biji anggur seperti resveratrol dapat memberikan suasana optimal pada saluran pencernaan dengan cara mengurangi bakteri pathogen dalam saluran pencernaan. Penggunaan biji anggur belum pernah dilakukan di dunia peternakan khususnya untuk mengurangi bakteri pathogen saluran pencernaan sehingga saluran pencernaan lebih bersih dan pencernaan zat makanan dapat berjalan optimal. Biji anggur akan mengeluarkan 
senyawa aktif seperti resveratrol yang mampu membunuh bakteri apabila dipanaskan. Beberapa penelitian asing melaporkan bahwa biji anggur memiliki kandungan senyawa kimia didalamnya sebagai anti inflamasi dan anti bakteri (Roh et al, 2014). Resveratrol mampu merangsang nafsu makan karena adanya bau yang terdapat pada metabolit sekundernya yakni resveratrol (Xia et al, 2010).

Penggunaan antibiotik dalam bentuk tepung ekstrak biji anggur sebesar 125 sampai $250 \mathrm{ppm}$ atau setara $0,012 \%-0,025 \%$ pada ayam broiler umur $0-42$ hari dilaporkan dapat menggantikan peran antioksidan sintetik seperti Beta Hidroxy Toluent (BHT). Dimana cara kerja BHT dapat merespon immunologi utamanya pada virus New Castle disease (ND) (Farahat, 2016). Penggunaan AGP tepung biji anggur kedalam pakan ayam layer fase statergrower digunakan dalam bentuk tepung karena penggunaan tambahan pakan dalam bentuk tepung memudahkan peternak untuk mencampur pakan satu dengan yang lain, selain itu pakan ataupun tambahan pakan dalam bentuk tepung akan memudahkan kerja saluran pencernaan ayam. Menurut Goodband, Et al (2002) dan Koch (1996) menyatakan bahwa pemberian pakan ataupun tambahan pakan seperti AGP bentuk tepung mempermudah akses enzim pencernaan pada ternak karena berkurangnya ukuran partikel pakan dan dapat mempermudah proses pencampuran pakan. Akan tetapi apabila terlalu halus akan menyulitkan unggas dalam mengkonsumsi pakan.

Oleh karena itu, diperlukan penelitian yang berjudul "Pertambahan Bobot Badan Harian (Pbbh) Pada Ayam Layer Stater-Grower Yang Diberi Resveratrol Tepung Biji Anggur".

\section{MATERI DAN METODE}

Metode yang digunakan dalam penelitian ini adalah Rancangan Acak
Lengkap dengan 4 perlakuan dimana masing-masing perlakuan menggunakan 3 ulangan ayam layer sater-grower. Perlakuan yang dilakukan adalah sebagai berikut :

P0 :Pakan komersial tanpa penambahan resveratrol tepung biji anggur

P1 : Pakan komersial $+0,012 \%$ resveratrol tepung biji anggur

P2 : Pakan komersial + 0,018\% resveratrol tepung biji anggur

P3 : Pakan komersial + 0,024\% resveratrol tepung biji anggur.

Setiap taraf perlakuan mendapat tiga ulangan dengan setiap ulangan terdiri dari lima ekor ayam. Perubahan yang diamati meliputi pertambahan bobot badan harian (PBBH). Pertambahan bobot badan (g/ekor) diperoleh dengan cara menghitung setiap minggu selisih antara bobot badan ayam akhir per minggu dengan bobot ayam awal umur 1 hari.

Pembuatan resveratrol tepung biji anggur dilakukan dengan cara biji anggur di jemur di bawah sinar matahari kurang lebih selama 2 hari kemudian di oven dengan suhu $60^{\circ} \mathrm{C}$ selama 1 jam. Setelah itu, biji anggur yang telah kering di grinding hingga halus dan membentuk tepung dan dicampur dengan pakan komersial sesuai masing-masing taraf perlakuan.

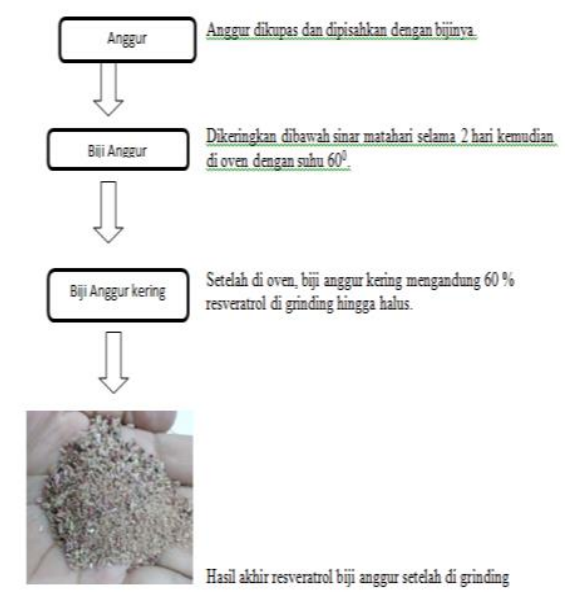

Gambar 1. Proses Pembuatan Tepung Biji Anggur. 


\section{HASIL DAN PEMBAHASAN}

Data hasil penelitian resveratrol biji anggur sebagai natural antibiotic growth promotore (N-AGP) terhadap pertambahan bobot badan ayam petelur dapat dilihat pada tabel 4.1.

Tabel 4.1. Hasil Penelitian resveratrol tepung biji anggur sebagai N-AGP terhadap pertambahan bobot badan ayam layer stater-grower.

\begin{tabular}{cc}
\hline & \multicolumn{2}{c}{ Variabel Yang Diukur } \\
\cline { 2 - 2 } Perlakuan & PBB $(\mathrm{gr} / \mathrm{hr})$ \\
\hline P0 & $12.27 \pm 0.30$ \\
P1 & $12.49 \pm 0.08$ \\
P2 & $12.85 \pm 0.30$ \\
P3 & $12.71 \pm 0.12$ \\
\hline
\end{tabular}

Rata-rata pertambahan bobot badan berdasarkan Tabel 4.1 menunjukkan efektivitas resveratrol biji anggur sebagai natural antibiotic growth promotore (N-AGP) terbaik adalah pada P2 (12.85 0.30$)$ cenderung lebih tinggi daripada P0 (12.27 \pm 0.30$), P 1$ (12.49 \pm 0.08) dan P3 (12.71 \pm 0.12). Untuk mengetahui efektivitas resveratrol biji anggur sebagai natural antibiotic growth promotore (N-AGP) terhadap pertambahan bobot badan dilakukan analisis statistik.

$\begin{array}{clr}\begin{array}{c}\text { Hasil analisis } \\ \text { menunjukkan }\end{array} & \text { bahwa } \\ \text { efektivitas }\end{array}$ resveratrol biji anggur sebagai natural antibiotic growth promotore (N-AGP) memberikan pengaruh yang tidak berbeda nyata terhadap pertambahan bobot badan ayam layer stater-grower $P$ $>0.05$. Hal ini dikarenakan komposisi pakan yang diberikan antar perlakuan adalah sama terutama pada kandungan karbohidrat, lemak, dan proteinnya. Suthama dan Ardiningsasi (2006) menyatakan bahwa aktivitas enzim pencernaan pada umumnya dapat dipengaruhi oleh faktor lain antara lain genetis, komposisi pakan dan intake. Resveratrol tepung biji anggur sebagai N-AGP yang ditambahkan dalam pakan memiliki kandungan nutrient pakan yang sama antar perlakuan. Jumlah substrat dari karbohidrat, lemak dan protein pada pakan yang sama akan menyebabkan reaksi enzim dalam mengubah substrat nutrient pakan tersebut menjadi produk daging adalah sama (Kampainen, 2002).

Bareto (2008), Martins et al., (2000) dan Huyghebaert (2003) menyatakan bahwa pemberian antibiotic herbal seperti dari ekstrak tanaman mengandung minyak esensial, saponin, tannin, karoten. Dimana dengan metode steam ekstraksi akan menghasilkan minyak esensial tanaman dalam jumlah yang lebih banyak. Minyak esensial inilah yang lebih bersifat bakteriostatik dan akan menghancurkan dinding sel pada bakteri gram negative usus halus unggas. Sehingga penyerapan nutrient pakan pada unggas akan lebih baik (Dorman dan Deans, 2000). Pemberian resveratrol tepung biji anggur sebagai N-AGP pada ayam layer stater grower dalam bentuk tepung dirasa kurang efektif karena tepung biji anggur dalam bentuk tepung kurang maksimal dalam mengeluarkan minyak esensial (resveratrol) pada biji anggur. Hal ini memungkinkan menjadi salah satu faktor yang menyebabkan hasil analisis statistic antar perlakukan tidak berbeda nyata $P>0.05$. sekaligus mematahkan penelitian terdahulu Menurut Goodband, Et al (2002) dan Koch (1996) menyatakan bahwa pemberian pakan ataupun tambahan pakan seperti AGP bentuk tepung mempermudah akses enzim pencernaan pada ternak karena berkurangnya ukuran partikel pakan dan dapat mempermudah proses pencampuran pakan. Akan tetapi apabila terlalu halus akan menyulitkan unggas dalam mengkonsumsi pakan.

Secara numerik terlihat perbedaan pertambahan bobot badan 
yaitu pada perlakuan yang diberikan resveratrol sebagai $\mathrm{N}-\mathrm{AGP}$ yaitu $\mathrm{P1}$ (12.49 \pm 0.08), P2 (12.85 \pm 0.30), P3 (12.71 \pm 0.12$)$ lebih baik dari pada PO (12.27 \pm 0.30$)$. Pemberian pakan dengan tambahan resveratrol sebagai N-AGP cenderung lebih baik dalam meningkatkan pertambahan bobot badan jika dibandingkan PO. Hal ini disebabkan oleh adanya resveratrol dalam pakan yang menyebabkan bau khas pada pakan sehingga dapat meningkatkan nafsu makan. Rose (1997) menyatakan bahwa secara garis besar, terdapat 2 faktor yang mempengaruhi kecepatan pertumbuhan, yaitu interaksi antara faktor genetik dan faktor lingkungan. Jenis spesies dan strain juga bangsa ayam tersebut merupakan faktor genetik. Kemampuan genetik akan terwujud secara optimal apabila kondisi lingkungan yang baik dan pemberian pakan yang efesien memungkinkan bagi ternak yang bersangkutan sehingga penampilan yang diharapkan dapat tercapai (Card dan Nesheim, 1972).

Selain itu dalam bentuk tepung, biji anggur sebagai Natural Antibiotik Gowth Promotore masih memungkinkan mengandung senyawa lain selain resveratrol yaitu fenol. Dimana fenol paling banyak ditemukan pada kulit, stem, daun dan biji dari anggur. Senyawa fenol dipercaya dapat digunakan untuk membunuh bakteri (bakterisid) (Xia et al., 2010). Efek baterisid pada biji anggur turut masuk dalam usus halus yang memungkinkan terjadinya perbaikan fungsi microflora usus halus sehingga penyerapan nutrient lebih baik dibandingkan kontrol.

Pertambahan bobot badan pada P3 $\left(\begin{array}{ll}12.71 \pm 0.12\end{array}\right)$ menunjukkan kecenderungan yang menurun jika dibandingkan dengan P2 (12.85 \pm 0.30). Hal ini dikarenakan pada P3 dimungkinkan tepung biji anggur yang digunakan sebagai natural antibiotic growth promotore masih mengandung saponin yang mempunyai rasa pahit. Saponin secara metabolisme dapat menurunkan kecernaan nutrient dalam pakan jika penggunaannya melebihi ambang batas dalam pakan. Gee et al. (1989) menyatakan bahwa saponin yang berasal dari beberapa macam tanaman akan mengakibatkan penurunan transmurai potential difference (TPD) sehingga menghambat transportasi nutrisi melintasi usus halus suatu tikus percobaan. Zhou et al (2014) menyatakan bahwa terjadinya asupan pakan yang mengakibatkan penurunan berat badan pada ayam petelur yang diberi ekstrak saponin alfalfa. Hal ini disebabkan kemungkinan adanya rasa pahit yang ditimbulkan dari saponin.

\section{KESIMPULAN DAN SARAN}

\section{Kesimpulan}

Penggunaan resveratrol tepung biji anggur sebagai natural antibiotic growth promotore N-AGP pada ayam layer stater-grower tidak memberikan pengaruh yang berbeda nyata $(P>0.05)$ terhadap pertambahan bobot badan.

\section{Saran}

Diperlukan penelitian lebih lanjut pada penggunaan biji anggur sebagai natural antibiotic growth promotore N-AGP bukan dalam bentuk tepung akan tetapi dengan metode lain seperti steam ekstraksi untuk mendapatkan Resveratrol Grape Seed Ekstract pada ayam layer stater-grower.

\section{DAFTAR PUSTAKA}

Balitvet, 1991; Murdiati dan Bahri, 1991 BALITVET. 1991 . Laporan penelitian residu pestisida, hormon, antibiotika dan standarsisasi kualitas broiler untuk ekspor. 
Bell, D. D \& W.D. Weaver, Jr. 2002. Comercial Chicken Meat and Egg Production. 5th Edition. Springer Science and Business Medial Inc, New York

Card, L. E \& m. C. Nesheim. 1972. Poultry Production. 11th Edition. Lea and Fibeger, Philadelphia.

Ensminger, M. E. 1992. Poultry Science. 3rd Edition. Interstate Publisher. Inc., Danville.

Goodband, Et al. 2002 dan Koch, 1996. Feed particle size: Implications on the digestion and performance of poultry. https://www.researchgate.net/pu blication/228361319_Feed_parti cle_size_Implications_on_the_di gestion_and_performance_of_p oultry

Indra, 2012.Super Foods Sehat dan Bugar dengan Beragam Pangan Fungsional Seharihari.FlashBooks. Jogyakarta.

Mu J.-J. He, Q.-H. Pan, F. He, C.-Q. Duan et al, 2013. Tissuespecific Accumulation of Flavonoids in Grape Berries is Related to Transcriptional Expression of $\mathrm{V}_{v} \mathrm{~F} 3{ }^{\prime} \mathrm{H}$ and $\mathrm{VvF} 3$ '5 ' $H$. Centre for Viticulture and Oenology, College of Food Science and Nutritional Engineering, China Agricultural University, Beijing 100083, S. Afr. J. Enol. Vitic., Vol. 35, No. 1,2014 .
News.detik.com, 2018. Pakan Ternak AGP Dilarang, Ayam di Blitar Diserang Penyakit https://news.detik.com/beritajawa-timur/d-3834256/pakanternak-agp-dilarang-ayam-diblitar-diserang-penyakit

North, M.O. and D.D. Bell. 1990. Commercial Chicken Production Manual. 4th Edition. Van Nostrand. Reinhold, New York

NRC (1994), Nutrient Requirements of Poultry.www.lamolina.edu.pe/fac ultad/zootecnia/biblioteca2012/N RC\%20Poultry\%201994[1].pdf

PT Ciomas Adisatwa. http://.japfacomfeed.co.id. 